medRxiv preprint doi: https://doi.org/10.1101/2020.07.17.20155333; this version posted July 19, 2020. The copyright holder for this preprint

\title{
SARS-CoV-2 viral load in the upper respiratory tract of children and adults with early acute COVID-19
}

Stéphanie Baggio ${ }^{1,2^{*}}$, Arnaud G. L`Huillier ${ }^{3,4,5^{*}}$, Sabine Yerly ${ }^{4}$, Mathilde Bellon ${ }^{4}$, Noémie Wagner $^{3}$, Marie Rohr ${ }^{3}$, Angela Huttner ${ }^{5}$, Géraldine Blanchard-Rohner ${ }^{3,6}$, Natasha Loevy ${ }^{7}$, Laurent Kaiser ${ }^{4,5,8}$, Frédérique Jacquerioz ${ }^{5,9,10}$, Isabella Eckerle Is, $^{4,8,11}$

${ }^{1}$ Division of Prison Health, Geneva University Hospitals, Geneva, Switzerland

${ }^{2}$ Office of Corrections, Department of Justice and Home Affairs of the Canton of Zurich, Zurich, Switzerland

${ }^{3}$ Children's Hospital of Geneva, Geneva University Hospitals and Faculty of Medicine,

Geneva, Switzerland

${ }^{4}$ Laboratory of Virology, Division of Laboratory Medicine, Geneva University Hospitals and Faculty of Medicine, Geneva, Switzerland

${ }^{5}$ Division of Infectious Diseases, Department of Medicine, Geneva University Hospitals and Faculty of Medicine, Geneva, Switzerland

${ }^{6}$ Center for Vaccinology and Department of Pediatrics, University Hospitals of Geneva, Geneva, Switzerland.

${ }^{7}$ Pediatric Platform for Clinical Research, Department of Woman, Child and Adolescent Medicine, Geneva University Hospitals and Faculty of Medicine, University of Geneva, Geneva, Switzerland

${ }^{8}$ Center for Emerging Viral Diseases, Geneva University Hospitals and Faculty of Medicine, Geneva, Switzerland

${ }^{9}$ Division of Tropical and Humanitarian Medicine, Geneva University Hospitals and Faculty of Medicine, Geneva, Switzerland NOTE: This preprint reports new research that has not been certified by peer review and should not be used to guide clinical practice. 
medRxiv preprint doi: https://doi.org/10.1101/2020.07.17.20155333; this version posted July 19, 2020. The copyright holder for this preprint (which was not certified by peer review) is the author/funder, who has granted medRxiv a license to display the preprint in perpetuity. It is made available under a CC-BY-NC-ND 4.0 International license.

${ }^{10}$ Primary Care Division, Geneva University Hospitals and Faculty of Medicine, Geneva, Switzerland

${ }^{11}$ Department of Molecular Medicine and Microbiology, Faculty of Medicine, Université de Genève, Geneva, Switzerland

*these authors have contributed equally

Corresponding author:

Isabella Eckerle, MD

Geneva Centre for Emerging Viral Diseases

Rue Gabrielle-Perret-Gentil 4

CH-1205 Geneva, Switzerland

Phone: +41223729820 / Fax: +41223724097

E-mail: isabella.eckerle@,hcuge.ch 
medRxiv preprint doi: https://doi.org/10.1101/2020.07.17.20155333; this version posted July 19, 2020. The copyright holder for this preprint (which was not certified by peer review) is the author/funder, who has granted medRxiv a license to display the preprint in perpetuity. It is made available under a CC-BY-NC-ND 4.0 International license.

\begin{abstract}
The role of children in the transmission of SARS-CoV-2 is unclear. We analysed viral load at the time of diagnosis in 53 children vs. 352 adults with COVID-19 in the first 5 days post symptom onset. No significant differences in SARS-CoV-2 RNA loads were seen between children and adults.
\end{abstract}


medRxiv preprint doi: https://doi.org/10.1101/2020.07.17.20155333; this version posted July 19, 2020. The copyright holder for this preprint (which was not certified by peer review) is the author/funder, who has granted medRxiv a license to display the preprint in perpetuity.

\section{Introduction}

Children are underrepresented in the current SARS-CoV-2 pandemic, and most infected children exhibit limited disease severity or are asymptomatic [1]. Although SARS-CoV-2 infects children of all ages, children do not seem to be major drivers of transmission, unlike for other respiratory viruses [2-4]. Current epidemiological data suggest a lower susceptibility among children, although most studies were performed while lock-downs/infection-prevention measures were in place, which included school closures [5]. Also, so far most documented pediatric infections originate from an adult case [2-4]. Furthermore, the role of children in spreading the virus to others is not well understood; in this regard, the kinetics and peak viral loads (VL), key determinants of virus transmission, have to be compared with VL of adults.

Recent SARS-CoV-2 RNA load comparisons across age groups have yielded inconsistent conclusions, finding similar or lower VL in children depending on the type of statistical analysis used, sample-collection time period, and diagnostic assay used [6-8]. Further understanding of VLs across age groups is relevant, as multiple studies established thresholds for the presence of infectious SARS-CoV-2, as assessed by isolation of culture-competent SARS-CoV-2 on cell lines [9-12]. Thus, viral RNA load can also serve as a surrogate of infectious virus shedding and potential transmission capacity.

In this single-centre study, we investigated SARS-CoV-2 RNA load from the URT at the time of diagnosis among symptomatic children and adults consulting our hospital in their first 5 days post onset of symptoms (DPOS).

\section{Methods}

\section{Study design and setting}

Data were collected in the context of prospective cohort studies at a single-centre. All diagnostic testing was performed at the virology laboratory of the Geneva University Hospitals 
medRxiv preprint doi: https://doi.org/10.1101/2020.07.17.20155333; this version posted July 19, 2020. The copyright holder for this preprint (which was not certified by peer review) is the author/funder, who has granted medRxiv a license to display the preprint in perpetuity. It is made available under a CC-BY-NC-ND 4.0 International license.

(HUG), a tertiary-care centre that serves the canton of Geneva and also serves as the Swiss National Reference Centre for Emerging Viral Diseases. Data on SARS-CoV-2 infected outpatients $\geq 16$ years old were collected at HUG's SARS-CoV-2 testing centre, and data on patients $<16$ years old were collected for all children who tested positive for SARS-CoV-2 in our laboratory.

\section{Participants}

Participants were included if they had a positive SARS-CoV-2 RT-PCR but excluded if 1) a previous positive SARS-CoV-2 test, 2) more than five DPOS 3) no symptoms at the time of diagnosis.

\section{Measures}

Diagnostic specimens consisted of nasopharyngeal swab samples collected with a flocked swab and stored in viral transport medium. Specimens in the presented analysis were either tested by an in-house method based on the Charité E gene assay or the Cobas 6800 SARS CoV2 RTPCR (Roche, Switzerland), targeting the E and the ORF1 gene, which were the two main diagnostic methods used in our Centre and showed a close correlation in terms of sensitivity and specifity [13]. A standard curve was obtained for both systems by quantifying in vitro transcribed RNA (in-house method) or quantified supernatant from a cell culture isolate of SARS-CoV-2 (Cobas) [10]. For both assays, a formula for calculation of VLs was obtained and SARS-CoV-2 RNA copy numbers from all samples were calculated from the cycle threshold values (CT values), in detail this was (CT-44.5)/-3.3372 for Cobas (E gene) and (CT41.7)/-3.4529 for the in-house assay (E gene). As VL was skewed, we used a logarithmic transformation $(\log 10)$. 
medRxiv preprint doi: https://doi.org/10.1101/2020.07.17.20155333; this version posted July 19, 2020. The copyright holder for this preprint (which was not certified by peer review) is the author/funder, who has granted medRxiv a license to display the preprint in perpetuity. It is made available under a CC-BY-NC-ND 4.0 International license.

Age. Age was collected at the day of the visit. The following categories were assigned: child (0-11), adolescent (12-19), young adult (20-45), and adult ( $>45$ years).

\section{Statistical analyses}

We calculated the sample size based on a correlation coefficient using $\mathrm{z}$ transformation[14]; with alpha $=.05$, power $=.80$, Pearson $r=.20$, the required sample size was $n=194$. We first computed descriptive statistics for all variables. We then tested the association between age and VL. We plotted age (continuous) against $\log 10 \mathrm{VL}$ and computed Pearson's correlation. Finally, we tested whether age groups were associated with VL using one-way analysis of variance, using post-hoc pairwise comparisons with Bonferroni adjustment between age groups and polynomial contrasts to identify trends. All analyses were performed with Stata 15 . The sample size calculation was estimated using www2.ccrb.cuhk.edu.hk/stat.

\section{Ethics}

The work was approved by the Cantonal ethics committee (no. 2020-00813; no. 2020-00835, no. 2020-00516). All study participants and/or their legal guardians provided written informed consent.

\section{Results}

For patients $\geq 16$ years old, we identified 352 patients fulfilling our inclusion criteria, that tested positive for SARS-CoV-2 in a selected time period between March 29 and April 23, 2020. For patients $<16$ years old, we identified 53 children fulfilling our inclusion criteria that tested positive for SARS-CoV-2 in a selected testing period between March 10, 2020 and 26 May, 2020. The total sample size was thus 405 . 
medRxiv preprint doi: https://doi.org/10.1101/2020.07.17.20155333; this version posted July 19, 2020. The copyright holder for this preprint (which was not certified by peer review) is the author/funder, who has granted medRxiv a license to display the preprint in perpetuity.

Mean age of all patients was $36.53 \pm 16.26$ years (range $0-82$ ); mean $\log 10 \mathrm{VL}$ was $6.06 \pm 1.98$ RNA copies/mL (range 1.52-9.42). Children and adolescents had a mean average VL of 6.13 \pm 2.02 (range 3.06-9.21) and $5.85 \pm 2.32$ (range 2.36-9.42) $\log 10$ RNA copies/mL, respectively, versus the two adult groups' (20-45 and $>46$ years) means of $5.91 \pm 1.88$ (range 2.37-9.39) and $6.33 \pm 2.05$ (range 2.49-9.39), respectively. VLs that lie above a postulated threshold for infectious virus shedding of around $6 \log 10$ RNA copies was reached for $49.5-$ $62.6 \%$ of patients (Supplementary table S1).

The correlation between age (continuous) and $\log 10$ VL was $r=.01(p=.797)$, as shown in Figure 1A. In the one-way analysis of variance, the association of age (categories) with VL was not significant $\left(F_{3,401}=1.34, p=.259\right)$. Neither post-hoc pairwise comparisons nor polynomial contrasts were significant (Bonferroni corrected p-values $\geq .333$; linear contrast: $F_{l}$, ${ }_{401}=0.29, p=.591$; quadratic contrast: $F_{1,401}=1.54, p=.216$ ). Figure 1B shows the relationship between age groups and $\log 10 \mathrm{VL}$.

\section{Discussion}

We compared VL among different age groups to clarify the role of children in SARS-CoV-2 transmission. Our main finding was that VL was similar across all age ranges, using age as a continuous variable and as a categorical factor.

In studies quantifying VL, observed thresholds for successful isolation were in the range of 5.4 - $7 \log 10$ RNA copies/mL, or a CT value of 24 and below for another study using only the testspecific CT for their correlation, which is expected to correlate with the same copy number range [9-12]. Here we could show that around half or more of all samples from both children and adults have a VL above such a threshold. In addition, we recently showed successful SARS-CoV-2 isolation from 12 of 23 children with COVID-19, with a median of $7.2 \log 10$ RNA copies/mL in culture competent samples [10]. 
medRxiv preprint doi: https://doi.org/10.1101/2020.07.17.20155333; this version posted July 19, 2020. The copyright holder for this preprint

A contested preprint of a study comparing viral loads of 3303 patients in Germany initially concluded that VL were similar across age groups, while a separate analysis of the same data set reported VL increased with age $[6,8]$. In a revised version of the original manuscript, similar VL across age groups were found in a setting at the beginning of the pandemic when mainly community and cluster screening was done [7]. Slightly lower VL in children was reported at a later stage when tested with another assay and when household testing was reduced. The above-mentioned study however lacks information on symptom onset date, and shows a large heterogeneity of study subjects included in the analysis (individuals tested as part of public health investigations but also patients). Thus potential inclusion of asymptomatic contacts and patients in later infection stages with declining VLs could be confounders. In our study, we included only patients presenting within the first 5 DPOS, as it was inferred that infectiousness peaks on or before symptom onset [15], with infectious virus presence largely limited to the first week of illness. Our findings, focusing on symptomatic patients during the early phase of disease, support an absence of difference in VL among children and adults in the first 5 days. One limitation of our study was a limited sample size of children, thus age group comparisons might have lacked power. Another limitation was inclusion of symptomatic patients only, thus not reflecting the whole spectrum of SARS-CoV-2 infection, especially the asymptomatic presentation frequently seen in children. Furthermore, we included patients tested by two different methods, however both of which showed close correlation for sensitivity, specificity and for VL quantification by an external standard curve.

To our knowledge, our study is the largest analysis on VL across age groups for which time of symptom onset is available, and here analysing age as a continuous variable clearly showed no relationship between VL and age. As we found similar VL in children versus adults and around half of specimens above a threshold correlated with infectious virus presence, our results suggest that the presumed lower transmission from children is not due to lower VL in the URT 
medRxiv preprint doi: https://doi.org/10.1101/2020.07.17.20155333; this version posted July 19, 2020. The copyright holder for this preprint

(which was not certified by peer review) is the author/funder, who has granted medRxiv a license to display the preprint in perpetuity.

It is made available under a CC-BY-NC-ND 4.0 International license.

compared to adults. As VL may not be the only factor for effective SARS-CoV-2 transmission, other factors might contribute to less efficient transmission in children, even with high VLs. Further studies are needed to understand the role of children in transmission, especially now that containment measures are lifted in most countries, to enable children to safely benefit from education and much needed social interactions among their peers.

\section{Acknowledgments}

We thank Claire-Anne Siegrist and Arnaud Didierlaurent for support of the study, Benjamin Meyer for help with data analysis and Erik Boehm for proof reading.

\section{Funding}

The study was funded by the Swiss National Foundation (SNF number 31CA30_196732/1, C.A. Siegrist), the Fondation de Bienfaisance du Groupe Pictet and the Fondation privée des HUG 
medRxiv preprint doi: https://doi.org/10.1101/2020.07.17.20155333; this version posted July 19, 2020. The copyright holder for this preprint (which was not certified by peer review) is the author/funder, who has granted medRxiv a license to display the preprint in perpetuity. It is made available under a CC-BY-NC-ND 4.0 International license.

\section{References}

1. Parri N, Lenge M, Buonsenso D, Coronavirus Infection in Pediatric Emergency Departments Research G. Children with Covid-19 in Pediatric Emergency Departments in Italy. N Engl J Med 2020.

2. Lu X, Zhang L, Du H, et al. SARS-CoV-2 Infection in Children. N Engl J Med 2020.

3. Posfay-Barbe KM, Wagner N, Gauthey M, et al. COVID-19 in Children and the Dynamics of Infection in Families. Pediatrics 2020.

4. Organization WH. Report of the WHO-China Joint Mission on Coronavirus Disease 2019 (COVID-19), 2020.

5. Davies NG, Klepac P, Liu Y, et al. Age-dependent effects in the transmission and control of COVID-19 epidemics. Nat Med 2020.

6. Jones TC, Mühlemann B, Veith T, et al. An analysis of SARS-CoV-2 viral load by patient age.

https://zoonosen.charite.de/fileadmin/user_upload/microsites/m_cc05/virologieccm/dateien_upload/Weitere_Dateien/analysis-of-SARS-CoV-2-viral-load-bypatient-age.pdf. (accessed 06.07.2020). 2020.

7. Jones TC, Mühlemann B, Veith T, et al. An analysis of SARS-CoV-2 viral load by patient age. medRxiv 2020.

8. Held L. A discussion and reanalysis of the results reported in Jones et al. https://osf.io/bkuar/ (accessed 06.07.2020), 2020.

9. Woelfel R, Corman, V.M., Guggemos, W. Clinical presentation and virological assessment of hospitalized cases of coronavirus disease 2019 in a travel-associated transmission cluster. 2020. 
medRxiv preprint doi: https://doi.org/10.1101/2020.07.17.20155333; this version posted July 19, 2020. The copyright holder for this preprint (which was not certified by peer review) is the author/funder, who has granted medRxiv a license to display the preprint in perpetuity. It is made available under a CC-BY-NC-ND 4.0 International license.

10. L'Huillier AG, Torriani G, Pigny F, Kaiser L, Eckerle I. Culture-Competent SARSCoV-2 in Nasopharynx of Symptomatic Neonates, Children, and Adolescents. Emerg Infect Dis 2020; 26(10).

11. van Kampen JJA, van de Vijver DAMC, Fraaij PLA, et al. Shedding of infectious virus in hospitalized patients with coronavirus disease-2019 (COVID-19): duration and key determinants. medRxiv 2020: 2020.06.08.20125310.

12. Bullard J, Dust K, Funk D, et al. Predicting infectious SARS-CoV-2 from diagnostic samples. Clin Infect Dis 2020.

13. Corman VM, Landt O, Kaiser M, et al. Detection of 2019 novel coronavirus (2019nCoV) by real-time RT-PCR. Euro Surveill 2020; 25(3).

14. Lachin JM. Introduction to sample size determination and power analysis for clinical trials. Control Clin Trials 1981; 2(2): 93-113.

15. He X, Lau EHY, Wu P, et al. Temporal dynamics in viral shedding and transmissibility of COVID-19. Nat Med 2020; 26(5): 672-5. 
medRxiv preprint doi: https://doi.org/10.1101/2020.07.17.20155333; this version posted July 19,2020 . The copyright holder for this preprint (which was not certified by peer review) is the author/funder, who has granted medRxiv a license to display the preprint in perpetuity. It is made available under a CC-BY-NC-ND 4.0 International license.

\section{Figure legend}

\section{Figure 1}

A. Scatterplot of age (continuous) against $\log 10$ viral load B. Means and $95 \%$ confidence intervals of $\log 10$ viral load against age groups.

\section{Supplementary files}

\section{Supplementary table 1. Descriptive statistics}

\begin{tabular}{lllll} 
Age categories & $\%(\mathrm{n})$ & Log10 viral load & Log10 viral load $>6^{2}$ & Symptoms onset (days) $^{1}$ \\
\hline Overall & $100(405)$ & $6.06(1.98,2.36-9.42)$ & $54.1(219)$ & $2.31(1.41)$ \\
Children (0-11) & $7.9(32)$ & $6.13(2.02,3.06-9.21)$ & $62.5(20)$ & $1.75(1.08)$ \\
Adolescents (12-19) & $6.7(27)$ & $5.85(2.32,2.36-9.42)$ & $51.9(14)$ & $2.30(1.46)$ \\
Young adults (20-45) & $52.8(214)$ & $5.91(1.88,2.37-9.39)$ & $49.5(106)$ & $2.36(1.45)$ \\
Adults $(46+)$ & $32.6(132)$ & $6.33(2.05,2.49-9.39)$ & $59.9(79)$ & $2.38(1.38)$
\end{tabular}

\footnotetext{
${ }^{1}$ Means, standard deviations, and range are reported.

${ }^{2}$ Percentages and $\mathrm{n}$ are reported.
} 
A

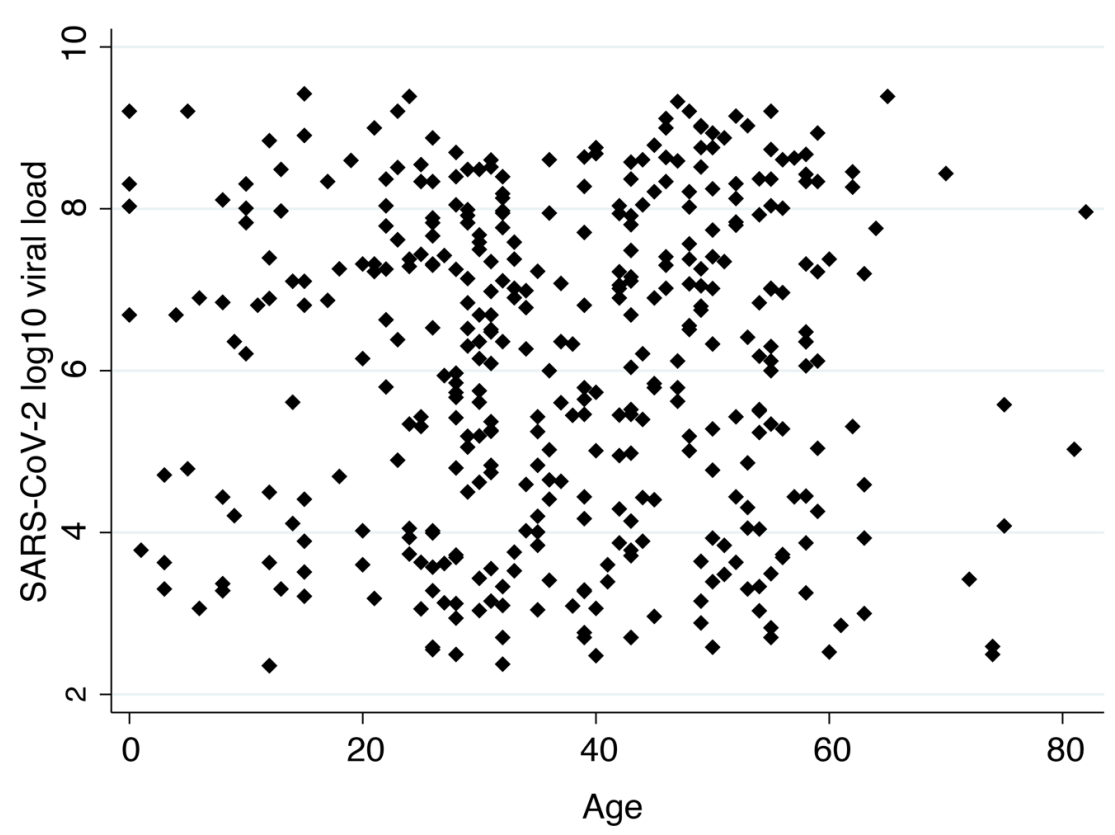

B

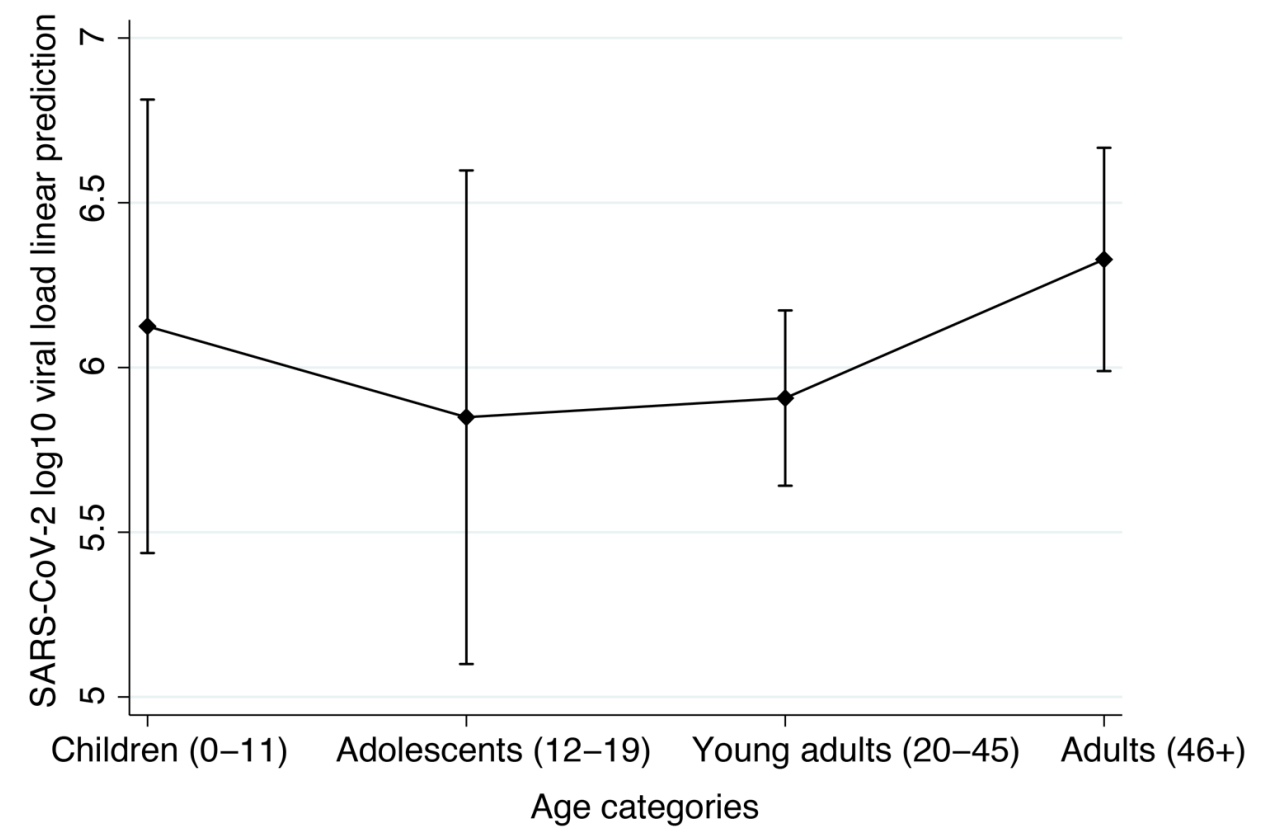

